\title{
Research and Application of Modern Japanese Teaching Methods
}

\author{
Lv Meijia \\ Jiangxi College Of Foreign Studies
}

\begin{abstract}
Learning language is not an isolated learning process. Any language is closely related to its unique social culture and background. Therefore, in Japanese teaching, not only to explain the Japanese language knowledge, training of the use of the Japanese language skills, but also pay attention to Japan's social and cultural, background knowledge of import. So a good way of learning is necessary. The application of multimedia technology in the teaching of Japanese is beneficial to the subjective initiative of teachers' classroom teaching, to stimulate students' initiative to learn Japanese, to excavate and expand the contents of Japanese language teaching, and to strengthen the effect of Japanese language learning. Fully embodies the stimulating and guiding role of multimedia technology, the use of multimedia technology to control the rhythm of the classroom, the development of multimedia teaching form, the use of multimedia to activate students' creative consciousness. In this paper, the structure of Japanese and Japanese culture, and then the combination of modern multimedia technology to learn how important it is.
\end{abstract}

Keywords-Japanese; Japanese teaching and research; multimedia

\section{INTRODUCTION}

With modern teaching ideas constantly updated, adhere to the teaching innovation, optimize educational resources, development and use of multimedia technology assisted teaching, will help to further improve the modern education. Scientific analysis and research multimedia technology, combined with the characteristics of Japanese teaching discipline, innovation and implementation of multimedia teaching application strategy in Japanese teaching process is the construction of scientific, efficient and diversified teaching philosophy of practical initiatives. I practice from a technical perspective of the application of multimedia technology in the Japanese language teaching.

Multimedia technology has friendly user interface and powerful information processing function. It can create vivid teaching environment through interactive technology. It can stimulate students' interest in a variety of senses, stimulate students' learning enthusiasm and improve their learning efficiency.

In traditional Japanese classroom, teachers mainly use blackboard, wall charts, tape recorders, etc. as a medium of knowledge architecture. Multimedia technology assisted instruction, teachers can promote active integration of teaching resources, optimizing teaching, integration of advanced teaching philosophy, rich Japanese language teaching content, improve instructional design, help to improve classroom teaching.

Structure of Japanese

In ancient times, Japanese only had the language without characters. Until the Sui and Tang Dynasty of China, with the introduction of Chinese characters into Japan die Japan begin to systematically use Chinese characters to record its own language. Initially, Chinese characters were used as phonetic symbols, namely Japanese syllables, with several Chinese characters. These Chinese characters later evolved into. "False" or "borrow", "name" is "the word"". Only use Chinese characters sound and form, without the sense of it, so called "kana". The direct use of its sound, form and meaning of the name is Chinese characters. So, in an article and use the real name, pseudonym, it is very confusing. Homonymous characters and kana have to borrow a lot, with more on the Chinese character strokes, use very convenient, so then the kana gradually simplified and create your own text, namely now "kana".

Hiragana: which was mainly used by women in ancient times. It consists of 48 characters, used to write 
native Japanese words, function words, verbs ending and to write those with formally approved the universal word cannot write Chinese loanwords.

Katakana: is a set of 48 -word composition. It is mainly used to writing outside the Chinese loanwords for emphasizing the onomatopoeia, or zoology and botany Japanese by kana (hiragana and katakana), Chinese, Roman words. I will introduce the following example to kana (hiragana and katakana) and Chinese characters. For example: これは日本语のテキストです (translated as: This is the Japanese textbook).

\section{JAPANESE CULTURE}

Japanese is very rich, not only the difference between spoken language and written language, but also the simplified and the king, and the ordinary and solemn, male and female, old and less difference. Different industries and positions of the people speak also different. This reflects the Japanese social caste and team thinking. The honorifics in Japanese developed. The use of honorifics makes public Japanese very elegant. But too complicated grammar makes difficult honorific learning. Even if the native Japanese are not fully skilled. The same honorific language has developed Tibetan, Mongolian, Korean.

Japanese pronunciation is very simple, only five vowel phonemes and very few consonants. With a variety of unusual pronunciation in total not more than 100 only. And the Japanese pronunciation similar in Spanish and Italian. In general, the proportion of these three languages in pronunciation of consonants and vowels of close to 1: 1 . Japanese vocabulary is very rich, and the large number of substantial absorption of foreign words. General vocabulary (not including the names and places) have more than 30,000 (1956).

Japanese and Altaic language family, the Austronesian language has a close relationship, under the influence of the Chinese great, absorbing the originally as Sino Tibetan characteristics of tone and quantifiers. Therefore, the Japanese language of belonging becomes very complicated. Linguists have different opinions on the origin of Japanese. Many scholars believe that, syntactically, Japanese and Mongolian language such as close to the soil's like the Altai language family. Japanese and Korean are similar in syntax is widely recognized.
There is also evidence, affect Japanese lexicon in prehistoric south by the Malay - Polynesian languages.

\section{THE REFORM OF MULTIMEDIA JAPANESE TEACHING MODE}

\section{A. Correctly Position the Function of Teaching Japanese with Multimedia}

Multimedia is used in Japanese class. Teachers use multimedia equipment designed by themselves to improve the efficiency of teaching. In the process of teaching Japanese, teachers should full realize the concrete functions of multimedia technology to avoid the full implementation of multimedia teaching and the class will be dominated by multimedia.

\section{B. Fully Embody the Stimulating and Guiding Role of Multimedia Technology}

In Japanese teaching, the use of multimedia technology assisted teaching, to combine the physical and mental development of students, the teaching content of the Japanese, through efficient technology, scientific and reasonable situation creation, to stimulate students to learn the interest of learning English and the initiative to explore the potential of learning.

\section{Use Multimedia Technology to Control the Process of Class}

Modern classroom teaching should really play and reflect the students' main position, we must protect the classroom atmosphere lively, lively and rigorous. In Japanese teaching, the use of multimedia teaching technology, appropriate and timely use of audio or video or animation effects, to help adjust and control the learning rhythm of students.

\section{Develop Multimedia Teaching Mode}

Multimedia teaching is a teaching method, not the ultimate goal, the focus is on how to appropriately use it to optimize and promote teaching. Japanese language teaching has a specific language practice characteristic, the use of a variety of multimedia teaching in the form of auxiliary teaching, we must focus on the Japanese language teaching objectives as the center.

\section{CONCLUSION}

Scientific analysis and research multimedia technology, combined with the characteristics of Japanese teaching discipline, innovation and implementation of multimedia teaching application strategy in Japanese teaching process is the construction of scientific, efficient and diversified 
teaching philosophy of practical initiatives. Multimedia technology and modern means of communication communications satellite, fiber optic transmission systems, combined to form a comprehensive, multi-channel, interactive information system will help the school, home, library, radio, television and other fused, will school, family, community education together, to build a modern teaching environment, modernizing education information dissemination. Only the rational application of modern technology to Japanese teaching, learning Japanese will become simple visualization, this paper based on the existing situation and the development of Japanese language teaching are analyzed, summed up the Japanese language is a mixture of many nations, but also to learn having a certain degree of difficulty, as long as the rational use of modern technology in order to better learn Japanese and Japanese culture.

\section{REFERENCES}

[1] Langlois R N, Steinmueller W E. Strategy and circumstance: the response of American firms to Japanese competition in semiconductors, 1980-1995[J]. Strategic Management Journal, 2000, 21(10-11):1163-1173.
[2] Nonaka, Ikujiro, and H. Takeuchi. The knowledge-creating company : how Japanese companies create the dynamics of innovation. Oxford University Press, 1995:592.

[3] Katayama, H. ,., et al. "Adverse reactions to ionic and nonionic contrast media. A report from the Japanese Committee on the Safety of Contrast Media.." Radiology 175.3(1990):621-8.

[4] Katayama H, Yamaguchi K, Kozuka T, et al. Adverse reactions to contrast media: Ionic versus nonionic: A report from the Japanese Committee on the Safety of Contrast Media[J]. Radiology, 1990, 175.

[5] Tinker, John N. Intermarriage and Ethnic Boundaries: The Japanese American Case1[J]. Journal of Social Issues, 1973, 29(2):49-66

[6] Shigenori, Maruyama, et al. "Paleogeographic maps of the Japanese Islands: Plate tectonic synthesis from $750 \mathrm{Ma}$ to the present." Island Arc 6.1(2006):121-142.

[7] Hou, Jilun, et al. "Cytological studies on induced meiogynogenesis in Japanese flounder Paralichthys olivaceus (Temminck et Schlegel)." Aquaculture Research 40.6(2008):681-686.

[8] Nonaka, I., \& Takeuchi, H. (1995). The knowledge-creating company : how Japanese companies create the dynamics of innovation. Oxford University Press.

[9] David H, Rena N, Faulkner K F, et al. Development of otolith receptors in Japanese quail[J]. Developmental Neurobiology, 2010, 70(6):436-455

[10] Association J G C. Japanese Classification of Gastric Carcinoma - 2nd English Edition -[J]. Gastric Cancer, 1998, 1(1):10-24.

[11] Higuchi T, Seki N, Kamizono S, et al. Polymorphism of the 5' - flanking region of the human tumor necrosis factor (TNF) - $\alpha$ gene in Japanese[J]. Tissue Antigens, 1998, 51(6):605-612.

[12] Nobutaka, Hattori, et al. "Molecular genetic analysis of a novel Parkin gene in Japanese families with autosomal recessive juvenile parkinsonism: evidence for variable homozygous deletions in the Parkin gene in affected individuals.." Annals of Neurology 44.6(1998):935-941 